\title{
The effect of the addition of wet brewers grain to the diet of lambs on body weight gain, slaughter value and meat quality
}

\author{
Aurelia Radzik-Rant ${ }^{1}$, Witold Rant ${ }^{1}$, Roman Niżnikowski ${ }^{1}$, Marcin Świątek ${ }^{1}$, Żaneta Szymańska $^{1}$, \\ Magdalena Ślęzak ${ }^{1}$, and Tomasz Niemiec ${ }^{2}$ \\ ${ }^{1}$ Department of Animal Breeding and Production, Warsaw University of Life Sciences-SGGW, \\ Ciszewskiego 8, 02-786 Warsaw, Poland \\ ${ }^{2}$ Department of Animal Nutrition and Biotechnology, Warsaw University of Life Sciences-SGGW, \\ Ciszewskiego 8, 02-786 Warsaw, Poland
}

Correspondence: Aurelia Radzik-Rant (aurelia_radzik_rant@sggw.pl)

Received: 15 January 2018 - Revised: 28 May 2018 - Accepted: 1 June 2018 - Published: 14 June 2018

\begin{abstract}
Wet brewers grain (WBG) is successfully used in animal nutrition, and due to its high fiber content, especially in ruminants. The low cost of this fodder also has an impact on the economic of production. The aim of this study was to determine the effects of adding WBG to lamb fodder on the body weight gain, slaughter value and meat quality. The experiment was conducted on 40 male lambs of Polish Lowland sheep. The lambs were divided into two feeding groups, the control and the experimental (20 heads in each group), and fattened to their slaughter weight of $40 \mathrm{~kg}( \pm 2.5 \mathrm{~kg})$. In the experimental group $35 \% \mathrm{WBG}$ was added to the feed. Lambs fed with WBG were characterized by higher daily weight gains $(P \leq 0.01)$ and reached their slaughter body weight significantly faster $(P \leq 0.01)$. Furthermore, the carcasses of the WBG group showed better hind leg conformation $(P \leq 0.01)$ and a higher content of prime cuts $(P \leq 0.05)$. The meat of lambs fed on WBG also had a lighter color and a lower intramuscular fat content. Additionally, the meat of this group was also characterized by higher PUFA $(P \leq 0.01)$ and $\mathrm{C} 18: 2$ cis 9 , trans 11 fatty acid $(P \leq 0.01)$ contents. The results obtained indicate that WBS could be successfully used in slaughter lamb production as a source of readily available, cheap fodder, especially when fattening takes place a short distance from a brewery.
\end{abstract}

\section{Introduction}

Brewers grain, a by-product of brewing industry, has the potential to be used as source of nutrition for farm animals, in both its wet and dry forms. It is also a good source of high quality protein and its energy and fiber contents range from 21 to $33 \%$, on a dry matter basis (Mussatto et al., 2006). Due to its high fiber content, brewers grain is particularly useful as a supplement to the diet of ruminants. The high fiber concentration stems from the fact that during the malting process the starches and sugars are removed from the barley grain leaving the structural carbohydrates, like cellulose and hemicellulose (Westendorf and Wohlt, 2002). The energy value of wet brewers grain (WBG) is around $71-75 \%$ of total digestible nutrients and is comparable with the energy value of corn grains. The total energy value of brewers grain is a combination of energy from highly digestible fiber and crude fat, which comprises $7-10 \%$ of the total product. Because WBG contains a relatively high water concentration $(74 \%$ on average) some consideration is required prior to its utilization as a feed source for ruminants, and the comparison of WBG to other fodder must be made on dry matter basis (Westendorf and Wohlt, 2002).

In addition to the high quality of protein and essential amino acids, WBG contains many other bioactive compounds. These include phenolic compounds, particularly ferulic and p-coumaric acid in addition to with oligosaccharides and polysaccharides (McCarthy et al., 2013; Mussatto et al., 2006). Due to the anti-cancer, anti-inflammatory and, 
above all, antioxidant activity of these compounds (Yang et al., 2001; Nagasaka et al., 2007), the use of brewers grain not only as an animal food but also as a food additive for humans is currently under consideration (Stojceska et al., 2008).

Due to the abovementioned high nutritional value, brewers grain has been used in animal nutrition for many years. It is particularly applicable in the nutrition of both dairy and beef cattle. Belibasakis and Tsirgogianni (1996) documented the use of WBG in the diet of dairy cows and noted a positive effect on milk yield and increases in the fat and dry matter content of the milk produced. Furthermore, in a study conducted by Peña and Posadas (2016), a $10 \%$ addition of brewers grain in lamb feed positively influenced the body weight growth increase of experimental animals in comparison to the control group. Previously, the fast development of body weight in growing lambs fed on $60 \%$ brewers grain had been noted by Aguilera-Soto et al. (2008). A further study on the effect of WBG use in fish feed also showed that brewery waste, which contained $19 \%$ protein and 18-20\% fiber, caused better carp growth results (Kaur and Saxena, 2004); this improved carp growth was imputed to the high quality protein contained in the WBG.

An analysis of the amino acid content in brewers grain showed a high amount of cysteine, lysine and methionine in addition to the presence of 14 other amino acids. This kind of composition indicates that brewers grain can be considered as an important component in poultry nutrition (Essien and Udotong, 2008). The inclusion of WBG to the diet of monogastric animals could also be beneficial for intestinal digestion, alleviating both constipation and diarrhea. These effects are attributed to the protein of this glutamine-rich content in addition to the high polysaccharide content and small amount of $\beta$-glucans (Tang et al., 2009).

In addition to the high nutritional value, using WBG in farm animal feeding can reduce the costs of nutrition. However, in order to obtain the desired economic benefits the farms needs to be located close to breweries. Brewers grain undergoes rapid spoilage due to its high moisture content and the presence of polysaccharides and proteins, which accelerate microbial activity. Methods of prolonging WBS storage time are also expensive and energy-intensive (Aliyu and Bala, 2011). Therefore, the transport of this fodder over long distances undoubtedly increases the cost of feeding in comparison to traditional nutrition, which was confirmed in a study by Ben-Hamed et al. (2011).

The aim this study was to determine the effect of the addition of brewers grain to lamb feed (kept on a farm near a brewery) on the fattening performance, the slaughter value and the quality characteristics and chemical composition of the meat.

\section{Materials and methods}

This research was conducted during September and October 2016 on ram lambs of Polish Lowland sheep. The lambs had an even body weight $(26.0 \mathrm{~kg} \pm 0.5 \mathrm{~kg})$ and were divided into two feeding groups, the control and the experimental, with 20 animals in each group. After a 14-days adaptation period, the lambs were fattened to achieve their slaughter weight of $40 \mathrm{~kg}( \pm 2.5 \mathrm{~kg})$.

Ethical approval for this experiment was obtained from the II Local Ethical Commission for Animal Experimentation in Warsaw (consent form number WAW2_20/2016). The animals were kept under uniform environmental conditions with constant zootechnical and veterinary supervision. The animals were housed in barn made of bricks, equipped with a usable loft and gravity ventilation. The control and experimental groups were kept on straw bedding in separate pens, with 20 animals in each pen.

The lambs were fed in groups according to the standards for fattening lambs up to a body weight of $30-40 \mathrm{~kg}$ (Osikowski et al., 1998). The lambs from the control group were fed with on a mixture of $28 \%$ meadow hay , $32 \%$ oatmeal, $39 \%$ steamed potatoes and $1 \%$ mineral mixture. In the experimental group a $35 \%$ share of WBG was used in the feed in combination with $18 \%$ meadow hay, $22 \%$ oatmeal, $24 \%$ steamed potatoes and $1 \%$ mineral mixture. The farm, where the experiment was conducted was located $1 \mathrm{~km}$ from a brewery, which ensured constant access to fresh, good quality WBG. The chemical composition and nutritional value of the fodder are presented in Table 1. Animals were fed twice a day, first at 07:00 LT and then again at 16:00 LT. The meadow hay was fed to the lambs separately. The oatmeal, potatoes and mineral mix for the control group, and the oatmeal, potatoes, brewers grain and minerals for the experimental group, were thoroughly hand mixed before each feeding. The feeds used were also weighed before each feeding. Refusals were not determined because all of the feed was eaten by the lambs. The animals had constant access to water.

In order to analyze the growth rate of lambs, control weighing was carried out. The lambs were weighed once at the beginning of fattening (after the adaptation period), then every 14 days and once again on the day of slaughter. On this basis the daily gain $\left(\mathrm{g} \mathrm{day}^{-1}\right)$ and total body weight gain $(\mathrm{kg})$ for the fattening period for each group were estimated.

After reaching the desired body weight lambs were slaughtered in a slaughterhouse according to accepted procedures. The slaughter value evaluation of carcasses was carried out after $24 \mathrm{~h}$ cooling at $+4{ }^{\circ} \mathrm{C}$ in the hanging position.

The carcasses were weighed and the hind leg length and perimeter were measured to calculate the hind leg tightness index according to method given by Niżnikowski (1988). The carcasses were then split longitudinally, and the two halves were weighed. Kidney and pelvic fat from the right side of the carcass were removed and weighed to obtain the kidney fat content for half a carcass. The right carcass halves 
Table 1. The chemical composition and nutritional value of feeds used in lambs fattening.

\begin{tabular}{|c|c|c|c|c|}
\hline Specification & Grass hay & Oatmeal & Steamed potatoes & Wet brewers grain \\
\hline Dry matter $\left(\mathrm{g} \mathrm{kg}^{-1}\right)$ & 870.4 & 873.5 & 192.8 & 260.9 \\
\hline Crude protein $\left(\mathrm{g} \mathrm{kg}^{-1} \mathrm{DM}\right)$ & 129.8 & 97.0 & 115.0 & 255.0 \\
\hline Ether extract ( $\left.\mathrm{g} \mathrm{kg}^{-1} \mathrm{DM}\right)$ & 22.0 & 34.0 & 3.0 & 59.0 \\
\hline Crude fiber $\left(\mathrm{g} \mathrm{kg}^{-1} \mathrm{DM}\right)$ & 317.0 & 120.0 & 37.0 & 147.0 \\
\hline Ash $\left(\mathrm{g} \mathrm{kg}^{-1} \mathrm{DM}\right)$ & 36.5 & 27.4 & 52.9 & 37.2 \\
\hline $\mathrm{EN}(\mathrm{MJ} / 1 \mathrm{~kg} \mathrm{DM})$ & 3.72 & 6.82 & 8.87 & 4.75 \\
\hline
\end{tabular}

EN: net energy; MJ: megajoule; DM: dry matter

were cut into joints according to methodology recommended by the National Research Institute of Animal Production (Krupiński et al., 2009). The joints were then weighed and the percentage of valuable cuts in each carcass half was calculated. The following joints were classified as valuable cuts: the rack, the loin and the hind leg.

Measurements of the width $(\mathrm{cm})$, depth $(\mathrm{cm})$ and area $\left(\mathrm{cm}^{2)}\right.$ of the longissimus dorsi muscle (LD) as well as fat thickness over the LD muscle ( $\mathrm{mm}$ ) were also performed.

The LD muscle was sampled in order to determine the quality traits of the meat from the lumbar region of each carcass. The samples were then vacuum packed and stored at $-22^{\circ} \mathrm{C}$ (for about 30 days) until chemical analysis was carried out.

The meat $\mathrm{pH}$ was measured $24 \mathrm{~h}$ after slaughter using an Elmetron CP-411 pH meter with a dagger electrode calibrated at $\mathrm{pH}$ values of 4.0, 7.0 and 9.0.

The water holding capacity was determined using the Grau and Hamm (1953) method modified by Pohj and Niinivaar (1957).

The meat color was determined $24 \mathrm{~h}$ after slaughter on the LD muscle surface using a Konica-Minolta CR-410 chroma meter, which specifies lightness $\left(L^{*}\right)$, redness $\left(a^{*}\right)$ and yellowness $\left(b^{*}\right)$.

The chemical composition and nutritional value of the lamb fodder were analyzed according to AOAC standard methods (1990).

The basic chemical composition of the LD muscle was determined by analyzing the moisture content, crude protein, intramuscular fat and collagen using a near-infrared transmission (NIR) spectrometric technique (PN-A-82109). The meat samples $(200 \mathrm{~g})$ were homogenized in an Elektrolux DITO K35 processor. Following this, unified samples were placed in the measuring cell of a FoodScan analyzer. This device uses near-infrared transmission in the $850-1050 \mathrm{~nm}$ range and is fitted with ANN calibration, which is developed using a model of artificial neural networks. The analysis is performed by indicating the number of sample measurements in the computer program, after which the program automatically calculates the average and presents the result.

The LD muscle samples were analyzed for fatty acid contents. The lipids from the muscle were extracted according to
Folsch et al. (1957). Saponification of fat took place in $0.5 \mathrm{M}$ $\mathrm{KOH}$ in methanol and esterification in $10 \% \mathrm{BF}_{3}$ in methanol. The fatty acid methyl esters were extracted into hexane.

The fatty acid profile of lipids was performed by gas chromatography using an Agilent Technologies GC $6890 \mathrm{~N}$ instrument equipped with a capillary column $\mathrm{BP} \times 70$ (length $60 \mathrm{~m}$, internal diameter $0.22 \mathrm{~mm}$, film thickness $0.25 \mu \mathrm{m}$ ). Operational conditions were as follows: helium gas (41 psi) and a FID detector at $240^{\circ} \mathrm{C}$. The temperature programme was $3 \mathrm{~min}$ at $130^{\circ} \mathrm{C}$, an increase to $235^{\circ} \mathrm{C}$ by $+2^{\circ} \mathrm{C} \min ^{-1}$ and then 4 min at $235^{\circ} \mathrm{C}$.

The fatty acids were identified via a reference material - BCR 163 (Beef/Pig Fat Blend). The isomer linoleic acid (CLA) was determined by standard cis-9, trans-11 octadecadienoic acid - Larodon AB, Sweden.

The statistical analyses of the data obtained was performed using the SPSS 23.0 software package (2016), based on a linear model that included the effect of the treatment group. In the analysis of the slaughter value the live body weight at slaughter was included in the model as a covariate. All effects were tested against residual middle-squares to determine the level of significance.

The results are presented as the means of the least squares for each trait (LSM) and the standard error (SE).

\section{Results and discussion}

An analysis of body weight growth showed that lambs fed WBG at the beginning of fattening, after the adaptation period, were characterized by a body weight which was approximately $0.45 \mathrm{~kg}$ higher than the control lambs, although the difference between groups was not statistically significant (Table 2). The addition of WBG in the lamb feed also resulted in animals reaching their slaughter body weight earlier $(P \leq 0.01)$, a higher rate of daily gain $(P \leq 0.01)$ and a higher total weight gain $(P \leq 0.01)$ during the fattening period in relation to the control group (Table 2). The faster growth rate of lambs fed dry brewers grain (DBG) (up to $45 \%$ ) as part of their diet was reported by Anigbogu (2003). Mullu et al. (2008)also found that using DBG in feed resulted in a higher daily growth rate and final body weight of local ram lambs of Wogera sheep. In contrast, Aguilera-Soto 
Table 2. Fattening results of the control and the WBG lambs.

\begin{tabular}{lrrr}
\hline Item & Control group & WBG group & SE \\
\cline { 2 - 3 } & LSM & LSM & \\
\hline Initial body weight $(\mathrm{kg})$ & 27.67 & 28.12 & 0.61 \\
Final body weight $(\mathrm{kg})$ & $39.44^{*}$ & $43.34^{*}$ & 0.82 \\
Fattening period $($ days $)$ & $61.79^{*}$ & $55.3^{*}$ & 1.50 \\
Average daily gain $\left(\mathrm{g} \mathrm{day}{ }^{-1}\right)$ & $188.62^{*}$ & $272.90^{*}$ & 12.16 \\
Total body weight gain $(\mathrm{kg})$ & $11.77^{*}$ & $15.22^{*}$ & 0.81 \\
\hline${ }^{*} P \leq 0.01$ & & &
\end{tabular}

Table 3. The hind leg and LD muscle measurements and traits for the control and the WBG lambs.

\begin{tabular}{lrrr}
\hline Item & Control group & WBG group & \multirow{2}{*}{ SE } \\
\cline { 2 - 3 } & LSM & LSM & \\
\hline Hind leg length $(\mathrm{cm})$ & 24.16 & 24.58 & 0.24 \\
Hind leg perimeter $(\mathrm{cm})$ & $38.61^{* *}$ & $40.40^{* *}$ & 0.41 \\
Hind leg tightness index $(\%)$ & 160.19 & 164.57 & 2.43 \\
Fat thickness over the LD muscle (mm) & 1.62 & 1.40 & 0.12 \\
Width of the LD muscle $(\mathrm{cm})$ & $5.98^{*}$ & $6.37^{*}$ & 0.11 \\
Depth of the LD muscle $(\mathrm{cm})$ & $2.73^{*}$ & $2.99^{*}$ & 0.07 \\
LD muscle area $\left(\mathrm{cm}^{2}\right)$ & 14.27 & 14.94 & 0.46 \\
\hline${ }^{*} P \leq 0.05 ; * * P \leq 0.01 ;$ Hind leg tightness index $=$ (hind leg perimeter $/$ hind leg length $) \times 100 \%$ &
\end{tabular}

et al. (2007) did not observe differences in the growth rate in their study between the control group, fed without WBG, and the experimental groups, fed feed supplemented with different levels of WBG, in crossbred Rambouillet $\times$ Pelibuey ewes. However, in a similar fashion to the present study, carried out on lambs, better results with regard to the faster growth rate and final body weight of heifers were obtained by Homm et al. (2008) using WBG; their study found that the best fattening results were obtained by adding between 15 and $30 \%$ WBG to the feed.

The linear measurements of the hind leg showed that lambs fed with WBG were characterized by a higher leg perimeter $(P \leq 0.01)$ and a greater, although not statistically confirmed, value of the leg tightness index in comparison to the control group (Table 3). This indicates better carcass conformation in lambs from the experimental group. The carcasses of the WBG group also showed higher values for the width and depth of the LD muscle $(P \leq 0.05)$. The LD muscle area was similar in both feeding groups and the fat thickness over the LD muscle was lower (although not statistically significant) in the group fed with WBG (Table 3). The opposite results were noted by Homm et al. (2008) in heifers, where the area of longissimus muscle decreased and the fattiness of the carcass increased along with the increase of WBG in the diet.

The results obtained at slaughter for the present study are presented in Table 4 . The cold dressing yield value was similar in both groups; a value above $42 \%$ is characteristic for meat/wool purpose lambs slaughtered at a body weight of approx. $40 \mathrm{~kg}$ (Kędzior, 1995). However, a greater carcass
Table 4. Slaughter and carcass traits of the control and WBG lambs.

\begin{tabular}{|c|c|c|c|c|}
\hline \multirow{2}{*}{\multicolumn{2}{|c|}{ Item }} & Control group & WBG group & \multirow[t]{2}{*}{ SE } \\
\hline & & LSM & LSM & \\
\hline \multicolumn{2}{|c|}{ Cold carcass weight $(\mathrm{kg})$} & $17.16^{*}$ & $18.39^{*}$ & 0.43 \\
\hline \multicolumn{2}{|c|}{ Cold dressing yield (\%) } & 44.00 & 42.49 & 0.88 \\
\hline \multirow[t]{2}{*}{ Kidney fat } & $\mathrm{kg}$ & 0.19 & 0.18 & 0.01 \\
\hline & $\%$ & $2.28^{*}$ & $1.99^{*}$ & 0.50 \\
\hline \multirow[t]{2}{*}{ Neck } & $\mathrm{kg}$ & 0.75 & 0.81 & 0.11 \\
\hline & $\%$ & 8.80 & 8.78 & 0.10 \\
\hline \multirow[t]{2}{*}{ Middle neck } & $\mathrm{kg}$ & $0.55^{* *}$ & $0.61^{* *}$ & 0.02 \\
\hline & $\%$ & 6.40 & 6.67 & 0.16 \\
\hline \multirow[t]{2}{*}{ Rib and flank } & $\mathrm{kg}$ & 1.51 & 1.53 & 0.04 \\
\hline & $\%$ & $17.61^{* *}$ & $16.65^{* *}$ & 0.21 \\
\hline \multirow[t]{2}{*}{ Shoulder } & $\mathrm{kg}$ & $1.28^{* *}$ & $1.42^{* *}$ & 0.04 \\
\hline & $\%$ & $14.87^{*}$ & $15.50^{*}$ & 0.18 \\
\hline \multirow[t]{2}{*}{ Rack } & $\mathrm{kg}$ & 0.55 & 0.57 & 0.02 \\
\hline & $\%$ & 6.37 & 6.20 & 0.02 \\
\hline \multirow[t]{2}{*}{ Loin } & $\mathrm{kg}$ & $0.60^{*}$ & $0.68^{*}$ & 0.02 \\
\hline & $\%$ & 7.01 & 7.37 & 0.17 \\
\hline \multirow[t]{2}{*}{ Hind leg } & $\mathrm{kg}$ & $2.34^{*}$ & $2.55^{*}$ & 0.06 \\
\hline & $\%$ & 27.40 & 27.73 & 0.21 \\
\hline \multirow[t]{2}{*}{ Valuable cuts } & $\mathrm{kg}$ & $3.49^{*}$ & $3.79^{*}$ & 0.09 \\
\hline & $\%$ & 40.77 & 41.30 & 0.26 \\
\hline
\end{tabular}

weight $(P \leq 0.05)$ was obtained from lambs from the experimental group compared to the control group. In terms of hind leg and loin weight and the overall content of valuable cuts, the carcasses of the WBG group displayed better results $(P \leq 0.05)$. Although the prime cuts include the hind leg, loin and rack, the shoulder can also be considered a valuable part of the carcass. The shoulder cut in the experimental group was found to weigh significantly more than in the control group $(P \leq 0.01)$. It is also worth noting that the kidney fat content was lower in carcasses of lambs fed WBG $(P \leq 0.05)$.

In general, the better conformation of the hind leg and lumbar region in combination with the favorable share of prime cuts, allows the opportunity to obtain more valuable culinary elements from lambs fed with a $35 \%$ WBG addition to their diet; this is of great importance to the sheep meat trade.

The analysis of the $\mathrm{pH}$ value measured $24 \mathrm{~h}$ after slaughter showed that the glycolysis process proceeded correctly in both groups. The values of this parameter ranged from 5.35 to 5.71, which is considered correct for sheep meat (Devine et al., 1993). However, a lower $\mathrm{pH}$ value in the control group $(P \leq 0.01)$, close to the isoelectric point of muscle proteins, could cause greater water loss from the meat, which was confirmed in this study by the analysis of the water holding capacity. Although differences in the value of this parameter between the groups were not statistically significant, meat from the WBG group of lambs turned out to be better in terms of this feature. Better water holding capacity in this 
Table 5. The meat quality traits of the control and WBG lambs.

\begin{tabular}{lrrr}
\hline Item & Control group & WBG group & SE \\
\cline { 2 - 3 } & LSM & LSM & \\
\cline { 2 - 3 } $\mathrm{pH}_{24 \mathrm{~h}}$ & $5.35^{*}$ & $5.71^{*}$ & 0.68 \\
Water holding & 9.56 & 7.98 & 0.89 \\
capacity $\left(\mathrm{cm}^{2} \mathrm{~g}^{-1}\right)$ & & & \\
\hline Meat color & & & \\
\hline Lightness $\left(L^{*}\right)$ & $34.96^{*}$ & $39.93^{*}$ & 0.66 \\
Redness $\left(a^{*}\right)$ & 17.14 & 16.28 & 0.42 \\
Yellowness $\left(b^{*}\right)$ & $1.89^{*}$ & $5.58^{*}$ & 0.44 \\
\hline$* P \leq 0.01$ & & &
\end{tabular}

Table 6. The chemical composition of the meat of the control and WBG lambs.

\begin{tabular}{lrrr}
\hline Item & Control Group & WBG group & \multirow{2}{*}{ SE } \\
\cline { 2 - 3 } & LSM & LSM & \\
\hline Protein $(\%)$ & 20.83 & 20.89 & 0.15 \\
Collagen (\%) & 1.23 & 1.01 & 0.08 \\
Fat $(\%)$ & $4.62^{*}$ & $2.92^{*}$ & 0.35 \\
Moisture (\%) & $73.91^{*}$ & $75.23^{*}$ & 0.38 \\
\hline$P \leq 0.05$ & & & \\
\hline
\end{tabular}

group may have resulted from a higher $\mathrm{pH}$ value (Table 5); the relationship between $\mathrm{pH}$ and the water holding capacity was confirmed in research conducted by Santos-Silva and Vaz Portugal (2001). Differences in the $\mathrm{pH}$ of beef meat were not noted by Shand et al. (1998), who also added WBG to the diet of an experimental group of steers; although the value of this parameter in the study by Shand et al. (1998) was similar to that obtained in present study for lamb meat from the experimental group.

Compared to the control group, a more favorable value of lightness $\left(L^{*}\right)(P \leq 0.01)$ was obtained in the in meat color analysis for lambs from the group fed with WBG (Table 5). A lighter meat color is very well perceived by consumers. According to Khliji et al. (2010) consumers accept meat, where the color parameters $a^{*}$ and $L^{*}$ are equal to or larger than 9.5 and 34.0, respectively.

The analysis of the chemical composition of meat showed no statistical differences between the examined groups regarding the content of crude protein and collagen (Table 6). The level of the latter component was within the limits relating to meat with good tenderness parameters (Purlsow, 2005). The intramuscular fat content was lower in the meat of lambs receiving WBG in their diet $(P \leq$ 0.05)(Table 6). However, different results were obtained by Shand et al. (1998), where in the experimental group fed WBG the intramuscular fat content was higher $(3.6 \%$ vs. $2,8 \%)$ than in the control group. The lower moisture content
Table 7. The fatty acid composition in the meat of the control and WBG lambs (values in ( $\mathrm{mg} / 100 \mathrm{~g}$ fat)).

\begin{tabular}{|c|c|c|c|}
\hline \multirow[t]{2}{*}{ The fatty acid } & Control group & WBG group & \multirow[t]{2}{*}{ SE } \\
\hline & LSM & LSM & \\
\hline $\mathrm{C} 8: 0$ & 0.01 & 0.02 & 0.00 \\
\hline $\mathrm{C} 10: 0$ & 0.12 & 0.12 & 0.00 \\
\hline C12:0 & 0.17 & 0.20 & 0.03 \\
\hline $\mathrm{C} 13: 0$ & 0.02 & 0.03 & 0.00 \\
\hline C14:0 & 2.72 & 2.88 & 0.29 \\
\hline $\mathrm{C} 15: 0$ & 0.54 & 0.52 & 0.04 \\
\hline $\mathrm{C} 16: 0$ & 23.56 & 23.66 & 0.37 \\
\hline $\mathrm{C} 17: 0$ & 1.86 & 1.50 & 0.13 \\
\hline C18:0 & 17.96 & 18.81 & 0.58 \\
\hline $\mathrm{C} 20: 0$ & $0.10^{*}$ & $0.13^{*}$ & 0.01 \\
\hline $\mathrm{C} 21: 0$ & 0.04 & 0.04 & 0.00 \\
\hline $\mathrm{C} 22: 0$ & 0.16 & 0.17 & 0.02 \\
\hline $\mathrm{C} 24: 0$ & $0.01^{*}$ & $0.02 *$ & 0.00 \\
\hline $\mathrm{C} 14: 1$ & 0.09 & 0.10 & 0.01 \\
\hline $\mathrm{C} 16: 1$ & 2.20 & 2.21 & 0.06 \\
\hline $\mathrm{C} 17: 1$ & 0.93 & 0.75 & 0.09 \\
\hline $\mathrm{C} 18: 1 \mathrm{n} 9$ & 39.48 & 38.07 & 0.64 \\
\hline $\mathrm{C} 18: 1 \mathrm{n} 7$ & $1.05^{*}$ & $0.86^{*}$ & 0.04 \\
\hline $\mathrm{C} 20: 1$ & 0.13 & 0.13 & 0.00 \\
\hline $\mathrm{C} 18: 2$ n6 & 3.55 & 3.87 & 0.17 \\
\hline $\mathrm{C} 18: 2 c 9, t 11$ (CLA) & $0.42^{*}$ & $0.54^{*}$ & 0.03 \\
\hline $\mathrm{C} 20: 2$ & 0.03 & 0.03 & 0.00 \\
\hline $\mathrm{C} 20: 3 \mathrm{n} 3$ & 0.07 & 0.07 & 0.00 \\
\hline $\mathrm{C} 20: 4 \mathrm{n} 6$ & 0.52 & 0.61 & 0.04 \\
\hline $\mathrm{C} 20: 5 \mathrm{n} 3$ & 0.04 & 0.06 & 0.01 \\
\hline $\mathrm{C} 22: 5 \mathrm{n} 3$ & 0.15 & 0.19 & 0.01 \\
\hline $\mathrm{C} 22: 6 \mathrm{n} 3$ & 0.11 & 0.16 & 0.03 \\
\hline$\Sigma$ SFA & 47.27 & 48.06 & 0.72 \\
\hline$\Sigma$ MUFA & 47.04 & 45.51 & 0.66 \\
\hline$\Sigma$ PUFA & $5.69^{* *}$ & $6.41^{* *}$ & 0.20 \\
\hline$\Sigma \mathrm{n}-6$ & 4.07 & 4.48 & 0.18 \\
\hline$\Sigma \mathrm{n}-3$ & $0.83^{*}$ & $1.02^{*}$ & 0.05 \\
\hline$n-6 / n-3$ & 4.89 & 4.43 & 0.24 \\
\hline PUFA / SFA & 0.12 & 0.13 & 0.01 \\
\hline MUFA / SFA & 0.99 & 0.95 & 0.03 \\
\hline
\end{tabular}

* $P \leq 0.05 ;{ }^{* *} P \leq 0.01$

in the meat from the control group $(P \leq 0.05)$ could be associated with the higher intramuscular fat content (Table 6). This is consistent with the fact that as the fattiness of the meat increases the water in the tissue is replaced by fat (Davis, 1989). Although higher intramuscular fat content may have a positive effect on meat tenderness and its culinary usefulness, most consumers are looking for lean meat.

Further analyses of the muscle tissue were performed to assess the fatty acid composition. Regardless of nutrition palmitic and stearic (C16:0 and C18:0) acid were dominated in the saturated fatty acid group (SFA) (Table 7). In the muscle tissue of lambs fed with WBG higher levels of longchain saturated fatty acids $\mathrm{C} 20: 0$ and $\mathrm{C} 24: 0$ were found 
$(P \leq 0.05)$. Despite the fact that differences in the content of polyunsaturated fatty acids (PUFAs) with 20 carbon atoms in the chain $(\mathrm{C} 20: 3, \mathrm{C} 20: 4, \mathrm{C} 29: 5, \mathrm{C} 22: 5, \mathrm{C} 22: 6)$ were not statistically confirmed, they were also found in higher levels in the intramuscular fat of the WBG group of lambs (Table 7). In addition to $\mathrm{C} 20$ fatty acids in the meat of lambs receiving WBG, higher levels of other acids $(P \leq 0.05)$ with a positive effect on human health, such as $\mathrm{C} 18: 3$ cis $9,12,15$ and $\mathrm{C} 18: 2$ cis 9 , trans 11 (CLA) as well as higher total PUFA content $(P \leq 0.01)$, including those belonging to $n-3$ family were found (Table 7). The reduced amount of intramuscular fat in the feed containing WBG could effect change in the ratio of complex fatty compounds for the benefit of phospholipids, in which most PUFAs are incorporated (Wood et al., 2008). Similarly, a higher content of C20 (C20:1, C24:1) acids in the intramuscular fat of steers fattened with WBG was found by Shand et al. (1998). However, the abovementioned study obtained a lower content of PUFA and higher SFA.

The ratio of $\mathrm{n} 6 / \mathrm{n} 3$ fatty acid in the meat of both study groups was similar, with $4.8: 1$ in the control group and $4.4: 1$ in the experimental group (those animals fed WBG) (Table 7). Such a ratio between these acid families is beneficial and recommended in human diet. The ratios of monounsaturated to saturated as well as polyunsaturated to saturated fatty acids were not statistically significant between the two study groups. A similar MUFA / SFA ratio in the meat of steers fed on WBG was reported by Shand et al. (1998), and earlier by Eichhorn et al. (1985).

\section{Conclusions}

Overall, the $35 \%$ addition of WBG in the experimental group's diet improved body weight gain, increased daily gains and shortened the fattening period. In addition, WBG did not reduced meat quality traits, but on the contrary, resulted in lower fattiness and the improvement of meat health benefits by increasing the PUFA and conjugated linoleic cis9, trans-11 acid content.

The results obtained indicate that WBG could be successfully used as easily available and cheap feed option in the production of slaughter lambs, especially when fattening is carried out a short distance from a brewery.

Data availability. The data are available from the corresponding author upon request.

Author contributions. ARR conceived and designed the study, performed the research, wrote the paper and assumed primary responsibility for the final content; WR performed the research, analyzed the data, conducted statistical data analysis and wrote the paper; RN conceived and designed the study, supported the design of the study, analyzed data and critically revised the paper; MŚw performed the research and analyzed the data; ŻS performed the research; MŚl performed the research; and TN performed the research.

All the authors read and approved the final manuscript.

Competing interests. The authors declare that they have no conflict of interest.

Edited by: Steffen Maak

Reviewed by: Vito Laudadio and one anonymous referee

\section{References}

Aguilera-Soto, J. I., Ramirez, R. G., Arechiga, C. F., Lopez, M. A., Banuelos, R., Duran M., and Rodriguez E.: Influence of wet brewers grain on rumen fermentation, digestion and performance in growing lambs, J. Anim. Vet. Adv., 6, 641-645, 2007.

Aguilera-Soto, J. I., Ramirez, R. G., Arechiga, C. F., MendezLlorente, F., Lopez-Carlos, M. A., Silva-Ramos, J. M., RinconDelgado, R. M., and Duran-Roldan F. M.: Effect of feed additives in growing lambs fed diets containing wet brewers grains, Asian-Aust. J. Amin. Sci., 21, 1425-1434, 2008.

Aliyu, S. and Bala M.: Brewer's spent grain: A review of its potentials and applications, Afr. J. Biotechnol., 10, 324-331, 2011.

Anigbogu, N. M.: Supplementation of dry brewers's grain to lower quality forage diet for growing lambs in Southeast Nigeria, Asian-Aust. J. Amin. Sci., 16, 384-388, 2003.

AOAC: Association of Official Analytical Chemists, Food Composition Additives Natural Contaminants 2.4 Oils and Fats, 963, 1990.

Belibasakis, N. and Tsirgogianni, D.: Effects of wet brewers grains on milk yield, milk composition and blood components of dairy cows in hot weather, Anim. Feed Sci. Techn., 157, 175-181, 1996.

Ben-Hamed, U., Seddighi, H., and Thomas, K.: Economic returns of using brewery's spent grain in animal feed, World Acad. Sci. Eng. Technol., 50, 695-698, 2011.

Davis, K.: Growth changes in the meat carcass. Meat production and processing, New Zeland Society of Anim. Prod., 11, 61-72, 1989.

Devine, C. E., Graafhuis, A. E., Muir, P. D., and Chrystall, B. B.: The effect of growth rate and ultimate $\mathrm{pH}$ on meat quality of lambs, Meat Sci., 35, 63-77, 1993.

Eichhorn, J. M., Bailey, C. M., and Blomquist, G. J.: Fatty acid composition of muscle and adipose tissue from crossbred bulls and steers, J. Anim. Sci., 61, 892-904, 1985.

Essien, J. and Udotong, I.: Amino acid profile of biodegraded brewers spent grains (BSG), J. Appl. Sci. Environ. Man., 12, 109-111, 2008.

Folch, J., Less, M., and Sloona Stanley, G. H.: A simple method for the isolation and purificationof total lipids from animal tissues, J. Biol. Chem., 266, 497-510, 1957.

Grau, R. and Hamm, R.: Eine einfache Methode zur Bestimmung der Wasserbindung im Muskel, Naturwiss, 40, 29-30, 1953.

Homm, J. W., Berger, L. L., and Nash, G.: Determining the corn replacement value of wet brewers grain for feedlot heifers, The Professional Animal Scientist, 24, 47-51, 2008. 
Kaur, V. and Saxena, P.: Incorporation of brewery waste in supplementary feed and its impact on growth in some carps, Bioresource Techn., 191, 101-104, 2004.

Kędzior, W.: Towaroznawcza charakterystyka jakości mięsa jagniąt, Zesz. Nauk. AE Kraków, Monogr., 123, 5-139, 1995.

Khliji, S., Van de Ven, R., Lamb, T. A., Lanza, M., and Hopkins, D. L.: Relationship between consumer ranking of lambs color and objective measures of color, Meat Sci., 85, 224-229, 2010.

Krupiński, J., Borys, B., Kieć, W., Knapik, J., Korman, K., Osikowski, M., Pompa- Roborzyński, M., and Rzepecki, R.: Assessment of the utility lambs meat against the requirements and methods used in the European Union, Institute of Animal Production, Cracow, 2009.

McCarthy, A. L., O'Callaghan, Y.C., Piggott, C. O., FitzGerald, R. J., and O'Brien N. M.: Brewers' spent grain; bioactivity of phenolic component, its role in animal nutrition and potential for incorporation in functional foods: a review, Proc. Nutrition Society, 72, 117-125, 2013.

Mullu, M., Berhan, T., and Alemu, Y.: The effects of supplementation of grass hay with different levels of brewer's dried grain on feed intake digestibility and body weight gain in intact Wogera lambs, East African J. Sci., 2, 105-110, 2008.

Mussatto, S., Dragone, G., and Roberto I.: Brewers' spent grain: generation, characteristics and potential applications, J. Cereal Sci., 43, 1-14, 2006.

Nagasaka, R., Chotimarkorn, C., Shafiqul, I. Md., Hori, M., Ozaki, H., and Ushio, H.: Antiinflammatory effects of hydroxycinnamic acid derivatives, Biochem. Biophys. Res. Comm., 358, 615-619, 2007.

Niżnikowski, R.: The Influence of cross-breeding of domestic corriedale ewes with rams of prolific and meat breeds on selected performance traits of their progeny, Scientific Dissertations and Monographs, Warsaw University of Life Sciences, 1988.

Osikowski, M., Porębska, W., and Korman, K.: Normy żywienia owiec, Normy żywienia bydła i owiec systemem tradycyjnym, IZ kraków, 29-57, 1998.

Peña, B. S. and Posadas, M. E.:. Supplementation Spent Grain from Waste Brewery in the Diet of Household Ovine System in the State of Mexico, J. Fisheries Livest. Prod., 4, 1000200, https://doi.org/10.4172/2332-2608.1000200, 2016.
PN-A-82109: Meat and meat products, Determination fat, protein and water content. The Near InfraRed Transmission Spectrometry (NIR) method using calibration on artificial neural networks (ANN), 2010.

Pohja, N. S. and Niinivaara, F. P.: Die Estimmung der Wasserbindung des Fleisches mittels der Konstandruckmethods, Fleischwirtschaft, 9, 193-195, 1957.

Purlsow, P. P.: Intramuscular connective tissue and its role in meat quality, Meat Sci., 70, 435-447, 2005.

Santos-Silva, J. and Vaz Portugal, A.: The effect of weight on carcass and meat quality of Scerra da Estrela and Merino Branco lambs fattened with dehydrated Lucerne, Anim. Res., 50, 289 298, 2001.

Shand, P. J., McKinnon, J. J., and Christensen, D. A.: Eating quality of beef from animals fed wet brewers' grains and wheat-based wet distillers' grains, Can. J. Anim. Sci., 78, 143-146, 1998.

SPSS Base 23.0 Users Guide, SPSS Inc., available: ftp://public.dhe. ibm.com (last access: 11 June 2018), 2016.

Stojceska, V., Ainsworth, P., Plunkett, A., and Ibanoglu S.: The recycling of brewer's processing by-product into ready-to-eat snacks using extrusion technology, J. Cereal Sci., 47, 469-479, 2008.

Tang, D., Yin, G., He, Y., hu, S.-Q., Li, B., Li, L., Liang, H., and Borthakur D.: Recovery of protein from brewer's spent grain by ultrafiltration, Biochem. Eng. J., 48, 1-5, 2009.

Westendorf, M. L. and Wohlt, J. E.: Brewing byproducts: Their use as animal feeds, VCNA, Food Animal Practice, 18, 233-252, 2002.

Wood, J. D., Enser, M., Fisher, A. V., Nute, G. R., Sheard, P. R., Richardson, R. I., Hughes, S. I., and Whittington, F. M.: Fat deposition, fatty acid composition and meat quality: A review, Meat Sci., 78, 343-358, 2008.

Yang, C. S., Landau, J. M., Huang, M. T., and Newmark, H. L.: Inhibition of carcinogenesis by dietary polyphenolic compounds, Ann. Rev. Nutr., 21, 381-406, 2001. 